\title{
IRISH FILM AND MEDIA STUDIES PUBLICATIONS
}

\author{
THE YEAR IN REVIEW - 2020 \\ Ciara Chambers (ed.)
}

Copyright (c) 2021 by the authors. This text may be archived and redistributed both in electronic form and in hard copy, provided that the author and journal are properly cited and no fee is charged for access.

\section{Introduction}

Ciara Chambers

\section{A Quiet Man Miscellany}

Des McHale

Stephen Boyd

Seáinín Tom Sheáin: From Arainn to the Silver Screen.

Tomás Ó hÍde

Denis Condon

Women in the Irish Film Industry: Stories and Storytellers

Edited by Susan Liddy

Abigail Keating.

Resilient Reporting: Media Coverage of Irish Elections since 1969

Michael Breen, Michael Courtney, Iain McMenamin, Eoin O’Malley and Kevin Rafter

Niamh Kirk

How Belfast Got the Blues: A Cultural History of Popular Music in the 1960s Noel McLaughlin and Joanna Braniff

Áine Mangaoang 


\section{Introduction}

\section{Ciara Chambers}

The Irish film and media studies publications section this year comprises an eclectic mix of film, journalism, music and folklore, as the traditional and contemporary spheres meet in research that considers the core issues of Irish representation: history, identity, gender and politics.

Abigail Keating explores Susan Liddy's much anticipated edited collection Women in the Irish Film Industry: Stories and Storytellers. The volume covers some of the most pressing concerns of the creative industries in Ireland in relation to the growing movement to address gender parity by filmmakers, programmers, funders and educators. Scholars, practitioners and policy makers address the historical and contemporary landscape of Irish cinema, celebrating some of the most significant female voices to have contributed to the Irish cultural arena. Studies based on qualitative and quantitative data, as well as textual analysis, present a revealing account of the current state of play and the work that still needs to be done to ensure a more diverse artistic community in Irish production. As Keating notes, visibility is a common thread running through many of the chapters "both in terms of shining a light on the multifaceted contributions of women to Irish film and film culture and on the mechanics and intricacies of the industry that impede women's progression within it". This is scholarship that is deeply embedded in activism, and will no doubt become a seminal text on Irish film courses across the world.

Stephen Boyd turns his attention to The Quiet Man Miscellany, a book that acknowledges the ubiquitous nature of "the most famous Irish film" in popular culture. In contextualising The Quiet Man's iconic status within the history of Irish cinema, Boyd acknowledges the problematic nature of defining what constitutes an Irish film. This is a complex and ongoing debate directly related to the fact that, for most of the twentieth century, Ireland did not have an indigenous film industry and dominant visual portrayals of Irish culture emerged from American and British depictions. Rather than an academic study, Des McHale's miscellany is a compendium of old and new information for "Quiet Maniacs", the fans of John Ford's film who enjoy deep dives into its production context and eternal appeal.

Áine Mangaoang describes how Noel McLaughlin and Joanna Braniff have uncovered hidden cultural narratives in their construction of a much-contested urban space through researching Belfast's interaction with popular music at a crucial point in Irish history. How Belfast Got the Blues: A Cultural History of Popular Music in the 1960s interweaves the fields of music, journalism, politics and film and considers both local and international acts in its construction of the city's musical history in a decade that remains significant both locally and internationally. The book considers the tensions between art, entertainment and commerce, juxtaposing these debates with Belfast's recent attempts to come to terms with its troubled past in a way that reflects upon (and often seeks to commercialise, particularly through tourism) its cultural legacies. Crucially the study considers the absences in these official narratives, acknowledging the importance of what alternative and underground forms can tell us about why gaps emerge in spatial and cultural histories. It is illuminating to consider how some of Belfast's forgotten figures, like Otillie Patterson, have contributed to broader musical developments, demonstrating the city's capacity to engage with the global music scene in ways that were "ahead of the curve" (446).

Niamh Kirk delves into Resilient Reporting, a study of news coverage of Irish elections from 1969 to 2016. Considering election reporting from the perspectives of journalism, political economy and media and cultural studies, Michael Breen, Michael Courtney, Iain McMenamin, Eoin O'Malley and Kevin Rafter analyse shifts in election 
coverage over time, interrogating the position of political reporting within broader media trends towards "infotainment". Large samples of newspapers, radio and television are considered to make some interesting arguments about generalised patterns in election reporting (for instance the clear link between poor government performance in the economy and more negative news coverage). Issues such as gender bias, the evolution of diverse content, ethics, values and the depiction of leaders and party policies are also considered.

Denis Condon reviews Tomás Ó hÍde's profile of actor and storyteller Seáinín Tom Ó Dioráin. Describing Seáinín Tom Sheáin: From Árainn to the Silver Screen as a "meticulously researched work of film history and folklore scholarship", Condon qualifies that Ó Dioráin's interaction with the silver screen was brief, but acknowledges the significance of his performance in Robert Flaherty's Oidhche Sheanchais (1934), the first sound film in the Irish language. The rediscovery of the film in 2012 highlights the ongoing capacity of restored archival material to illuminate debates on Irish cinema and the book addresses many archival gaps by reconstructing and exploring all of Ó Dioráin's recorded folklore, including transcriptions, filmed performances and audio recordings. Indeed, this is a year when the archive has yielded many creative ways to make film as a means of circumventing the restrictions imposed by the pandemic, and it is with this in mind that this introduction finishes with a shameless plug for the Make Film History project. In an attempt to reduce the traditional barriers to access between student filmmakers and archival providers, the initiative makes collections from the Irish Film Institute, the British Film Institute, BBC Archive Editorial and Northern Ireland Screen available for non-commercial reuse. Funded by the AHRC and the Irish Research Council, the partnership between University College Cork, Kingston School of Art and the archives has opened up a diverse range of Irish and British material to students across the UK and Ireland. A series of workshops on creative reuse as well as public events with filmmakers is ongoing. More information on the project is available here:

https://www.archivesforeducation.com/makefilmhistory

Ciara Chambers is Head of the Department of Film and Screen Media, University College Cork, author of Ireland in the Newsreels (Irish Academic Press, 2012) and co-editor of Researching Newsreels: Local, National and Transnational Case Studies (Palgrave, 2018). She is a member of the council of the International Association of Media and History and associate editor of the Historical Journal of Film, Radio and Television. She was screenwriter and associate producer of the six-part television series Eire na Nuachtscannán which was broadcast on TG4 in 2017, 2018 and 2019. www.irelandinthenewsreels.com

Ciara.chambers@ucc.ie

A Quiet Man Miscellany

Des McHale

Cork: Cork University Press, Cork, 2020, 216 pp.

ISBN: 9781782053866

Reviewer: Stephen Boyd (Institute of Art, Design and Technology, Dun Laoghaire)

John Ford's The Quiet Man (1952) is very likely the most written about "Irish" film of all time, and Des McHale may be the film's most informed fanatic. A Quiet Man Miscellany is 
McHale's third book about the film, his first being the highly informed The Complete Guide to the Quiet Man (2000), followed by Picture the Quiet Man (2004). In this latest book he continues his quest to uncover every possible detail about the iconic film and the minutiae of its production during the summer of 1951.

Ford's Irish-American fantasy, based on the short story by Maurice Walsh, is one of the most important texts within the visual culture of Irish Studies. When Ford made The Quiet Man there was no major film industry on the island of Ireland. The void in international representation from within meant that American cinema was able to frame Ireland - its landscapes, culture and people - and to establish an "idea" of Ireland to its audience that persists to this day. Indeed this image of Ireland "set a template for Ireland's promotion of itself through tourism" (Crosson 1) and is worth a tidy annual sum to the industries that sell Irishness in the United States (Casey 84-109). This is Ireland, but seen through a romantically idyllic lens in which "its Technicolor vision of a land of rosy cheeked colleens, leprechaunlike intercessionaries and humane clergy united by song, drink and public brawling had little in common with the Ireland of the 1920s in which it is ostensibly set" (Barton 72-3). Ford wasn't attempting to depict a social reality, "but to recreate a myth" (Curran 79-80). Just as his Westerns significantly influenced a constructed "idea" of America and the Old west, John Ford was able to draw on a series of already established romantic conventions to create an "idea" of Ireland that would be depicted in artistic and touristic imagery for decades to follow. This was an Ireland, as Martin McLoone describes, of "benign utopias of romantic pastoralism" (McLoone 34). To fully understand the importance of The Quiet Man in the study of Irish cinema, one must also understand the cinematic response in Ireland to the imagery it created. From the emergence of sustained indigenous production in the $1970 \mathrm{~s}$, The Quiet Man inspired a range of cinematic ripostes to its cartoonish representation of the West of Ireland, from Bob Quinn's Poitin (1977), the anti-Quiet Man, to Jim Sheridan's cinematic adaptation of John B. Keane's The Field (1990).

The sustained focus on The Quiet Man by academics over the last forty years has called into question the notion of what exactly constitutes an Irish film, and how the subject of Irish cinema should be studied. Regardless of what academia thought, the film was voted as the best "Irish" film of all time in a 1996 Irish Times poll (Crosson 2) and the critics Tara Brady and Donald Clarke recently placed the film seventh in their "Top 50 Irish films of all time" (2020). The film has also helped to inspire some of the best academic work in studies of Irish cinema, such as Luke Gibbons' influential analysis of "Romanticism and Realism in Irish Cinema" (194-257).

The film is also of unique importance because of its relationship with a diasporic Irish identity. In the sleeve McHale points out that the film is a "powerful evocation of nostalgic Ireland and the search for home" (2020), and perhaps we could add, in the case of many Americans, a sense of Irish cultural identity. This nostalgia was key to many of the Irish emigrant fantasies of return made in American cinema, which can be seen in the early Kalem Company films such as The Lad From Old Ireland (1910). Lance Pettitt argues that in fact "the film's enduring popularity may be explained by [...] the way it portrays the romantic reintegration of an Irish émigré" (64). James McKillop describes this as the work of a "third generation (emigrant) return literature" that seeks out an Ireland "lost from family memory" (180). This postmodern nostalgia for a world that never existed in the first place is now an established part of the "tourist gaze" by which Ireland is imagined by others. The restoration of The Quiet Man cottage in Cong, County Mayo as a site of pop cultural pilgrimage shows how cultural heritage becomes theme park via the technicolour prism of 1950s Hollywood cinema.

McHale's book is a true miscellany, containing an assortment of freshly published information and archival material. Of particular interest is a chapter featuring the letters of 
Meta Sterne, John Ford's script supervisor and regular assistant. Sterne was extremely close to Ford, and her letters to her husband Sam Kalish offer the greatest insights into behind the scenes aspects of the production, although Sterne herself seems to have been mainly concerned about the paucity of the local food, "We've not had a vegetable hot save potatoes and carrots. I ate some soup and found two pieces of string bean and almost wept" (3).

There are ten short eclectic chapters in total. One makes a brief comparison between the film and its informal cinematic cousin, Only the Lonely (1991), in which Chris Columbus imagined an older version of Maureen O'Hara's Mary-Kate Danaher in the character of Rose Muldoon. Another chapter focuses on the role of Welsh author Richard Llewellyn in the adaptation of Walsh's short story to the final shooting script. Llewellyn was not credited (that honour went to Frank Nugent) as Ford deemed his script too political, but much of his influence on the film remained. For example, the names "Inisfree" and "Castletown" were Llewellyn's ideas (45). Other chapters include sections on the groundbreaking "New Perspectives on the Quiet Man" conference of 2005 held at the Huston School of Film and Digital Media at NUI Galway. Another describes the memories of minor cast member Maureen Coyne (who played old Dan Tobin's daughter). The final chapter even offers a quiz.

McHale does not come from the academic establishment that usually make it their business to critically analyse films like The Quiet Man; he has had a long career as an academic in mathematical science as an expert on the work of George Boole and has published numerous books of jokes and humour. A Quiet Man Miscellany is therefore atypical with regard to mainstream criticism or analysis but no less valuable in terms of knowledge of the film. This book is not the detailed and sustained critique that one might expect from an academic in the field of film or screen studies, but to assess the book in this manner would miss the point. More than any other film which represents the Irish on screen, The Quiet Man has taken on a life of its own in contemporary popular culture and boasts a large online fan base. McHale's methodology is in his fanatical obsession with knowledge about the film, and this approach has provided a huge amount of data on the subject. The book features some excellent on set photography and an array of production stills alongside some genuinely interesting facts; at other moments some of the facts and titbits are not quite as revelatory as they set out to be.

MacHale isn't the first author to write a guidebook to the film. Luke Gibbons wrote a brief critical text on the film (2002), and others have published about the film outside of academia (McNee, 2008; Young, 2012). There have also been informative documentaries which offer similar insights to MacHale's book. Examples include Se Merry Doyle's John Ford: Dreaming the Quiet Man (2010), Inisfree This Way (1991), and The Making of the Quiet Man with Leonard Maltin (1992). It could be argued that this profusion of information and reverie about The Quiet Man renders McHale's third book superfluous, but given the socio-historical importance of the film the book is a welcome addition to the existing corpus of work on the subject.

The Quiet Man Miscellany is a light text aimed at fans of the film, for whom the book will hold great value. In a chapter solely entitled "Miscellany" which lists a series of paragraphs offering even more miscellaneous information from the film, McHale asks "just what level of detail does one have to reach before the typical Quiet Maniac's insatiable thirst for knowledge about the movie is satisfied?" (95). The answer it seems, is to considerable levels. McHale has a deep understanding of the film and his publications will be useful to any student or researcher who desires to know every possible detail about the film. Ultimately though, A Quiet Man Miscellany may be of most interest to those out there who consider themselves true "Quiet Maniacs". 


\section{Works cited}

Barton, Ruth. Irish National Cinema. London: Routledge, 2004.

Brady, Tara and Donald Clarke. "The 50 Best Irish Films Ever Made, in Order." The Irish Times. 2 May 2020. www.irishtimes.com/culture/film/the-50-best-irish-films-evermade-in-order-1.4238979.

Casey, Natasha. "The Best Kept Secret in Retail: Selling Irishness in Contemporary America." The Irish in Us: Irishness, Performativity, and Popular Culture. Ed. Diane Negra. London: Duke University Press, 2006. 84-109.

Crosson, Sean and Rod Stoneman. The Quiet Man and Beyond: Reflections on a Classic Film, John Ford, and Ireland. Dublin: Liffey Press, 2009.

Curran, Joseph. P. Hibernian Green on the Silver Screen: The Irish and American Movies. New York and London: Greenwood Press, 1989.

Gibbons, Luke. The Quiet Man (Ireland into Film Series). Cork: Cork University Press, 2002.

McKillop, J. (1999). "The Quiet Man Speaks." Contemporary Irish Cinema: From The Quiet Man to Dancing at Lughnasa. Ed. J. McKillop. Syracuse, New York: Syracuse University Press, 1999. 169-81.

McBride, Joseph. Searching for John Ford: A Life. New York: St. Martin's Press, 2001.

McHale, Des. The Complete Guide to the Quiet Man. Dublin: Appletree Press, 2000.

- Picture The Quiet Man. Dublin: Appletree Press, 2004.

McLoone, Martin. Irish Film: The Emergence of a Contemporary Cinema. London: British Film Institute Publishing, 2000.

McNee, Gerry. In the Footsteps of the Quiet Man. Edinburgh: Mainstream Publishing, 2008.

Pettitt, Lance. Screening Ireland: Film and Television Representation. Manchester and New York: Manchester University Press, 2000.

Rockett, Kevin, Luke Gibbons and John Hill. Cinema and Ireland. London and New York: Routledge, 1987.

Walsh, Maurice. The Quiet Man and Other Stories. Belfast: Appletree Press, 2002.

Young, Jordan. R. John Ford's The Quiet Man: The Making of a Cult Classic. Epub: Past Times Publishing Company, 2012.

Stephen Boyd lectures in Film and Screen Media at the Institute of Art, Design and Technology in Dun Laoghaire, County Dublin. He is also a $\mathrm{PhD}$ researcher at Trinity College Dublin.

Stephen.boyd@iadt.ie

Seáinin Tom Sheáin: From Árainn to the Silver Screen.

Tomás Ó hÍde.

Dublin: Comhairle Bhéaloideas Éireann, 2019. xiv + 267 pp.

ISBN: 978-0-9565628-8-3

Reviewer: Denis Condon (Maynooth University, Ireland)

Seanchai (storyteller) and unlikely leading man Seáinín Tom Ó Dioráin (early 1870s-1939) gazes out at the reader with an enigmatic smile from the cover of Tomás Ó hÍde's meticulously researched work of film history and folklore scholarship. The book's subtitle is somewhat misleading, suggesting a Hollywood rag-to-riches narrative, but Ó Dioráin's 
moment as a storyteller on the silver screen rather than on Inishmore was brief. Rather than offering a star study, then, this book does two main things: it collects the recorded stories and other folklore of Ó Dioráin, and it pays particular attention to one piece of that folklore: his performance of the story "Máirtín Mac Conraoí" in the film Oidhche Sheanchais, the first sound film in the Irish language, which was sponsored by the Irish government and directed by pioneering American documentarist Robert Flahery in 1934 during the final stage of the production of Man of Aran. Long thought lost, Oidhche Sheanchais was rediscovered at Harvard University in 2012. After restoration, it was shown at several film festivals and other special events in 2014 and 2015 and by the Irish-language broadcaster TG4 in 2016. In the wake of the rediscovery, a number of scholars published analyses of the film, not least Ó hÍde himself who contributed articles on it to New Hibernia Review in 2014 and to this journal in 2016.

For readers of this review, the chapters focusing on the film are likely to be of most interest, and Ó hÍde is well aware that apart from readers who will read the book all the way through, he is addressing two other main constituencies: those interested in the film and those interested in the folklore. In the preface, he directs those interested in Oidhche Sheanchais to chapters 3, 4 and 6 (xi). Readers interested in an aspect of the folklore or even a particular tale can navigate the book easily thanks to detailed chapter breakdowns in the contents pages and helpful appendices listing both Ó Dioráin's recorded repertoire and tale types and motifs. The book is fully accessible to readers with little or no Irish, all tales and virtually all other Irish texts being translated by the author.

Although the book grew out of Ó hÍde's work on Oidhche Sheanchais, its primary purpose is to present all Ó Dioráin's recorded folklore, regardless of whether the recording medium was written transcription, filmed performance or audio recording, and its structure reflects this. Chapters 2, 7 and 8, the chapters that surround the film chapters, are concerned with the written transcription of Ó Dioráin's folklore, while chapter 5 discusses the audio recording of two of Ó Dioráin's stories in London for release on a gramophone record. As such, other players vie with featured star Ó Dioráin for the limelight in Ó hÍde's account, particularly Seósamh Ó Flannigáin, a local teacher and folklore collector on Inishmore, and folklore scholar Séamus Ó Duilearga, who was tasked by the Irish Department of Education with finding a suitable storyteller for the film they had asked Robert Flaherty to make.

While the film remains at the core of the book, there is a tension between its varying importance to film studies and folklore. For folklore scholars, "Máirtín Mac Conraoí" forms only a small part of Ó Dioráin's corpus, and for film scholars, this is a little-seen approximately elven-minute, simply staged film whose ostensible purpose was to provide an example of spoken Irish for school children learning the language. Despite that tension, Ó hÍde shows that the film's interest and importance expand at the intersections of Irish film studies and folklore. Because that intersection is his focus, the book's research questions concern the seanchai and the story he tells. Ó hÍde explores how Ó Diorán became the chosen storyteller when he was neither Flaherty's nor Ó Duilearga's first choice. His questions on the story include not only the choice of "Máirtín Mac Conraoi'" and where it fits in Ó Doiráin's recorded corpus but also why the version of the story told during rehearsals differed so markedly from the one performed the following day before the camera.

Those questions are not obvious film studies questions, and film studies scholars coming to the book looking for insights into Flaherty's working methods, for example, will be somewhat disappointed. Flaherty makes some cameo appearances, but he does not play the major role that Ó Duilearga does in the folklorist account offered here. The reader learns almost as much about Adolf Mahr, the Austrian-born Keeper of Irish Antiquities at the National Museum of Ireland, whom both Flaherty and Ó Duilearga consulted and who was leader of the Dublin branch of the Nazi party. Nevertheless, even readers familiar with the 
existing scholarship on the film since its rediscovery will learn new details. Focused on the storyteller and his story, the book documents Ó Dioráin and Ó Duilearga's journey from Inishmore via Dublin to Gainsborough Studios in London, where Oidhche Sheanchais was shot in January 1934 during the dubbing of Man of Aran on a set designed to look like a hearth in a cottage in the west of Ireland. While Ó hÍde has previously analyzed the staging of the film, here he pays more attention to the two versions of "Máirtín Mac Conraoi" recorded during these few days, the first at the rehearsal written down by Ó Duilearga and preserved in the collections of the National Folklore Commission (NFC) and the second captured on the film's soundtrack. Ó hÍde also makes use of Ó Duilearga's notes for a screenplay based on that rehearsal but observes that Flaherty chose to ignore these and produce a much simpler film based solely on the material shot in the studio and favouring reaction shots of the onscreen auditors for Ó Dioráin's story, particularly Man of Aran star Maggie Dirrane, who opens Oidhche Sheanchais with a song and has more screen time overall than Ó Dioráin. Although Ó Duilearga left no notes from the time he spent in April 1934 as the Irish-speaking consultant on the editing of the film, Ó hÍde demonstrates that it must have been at that point that he prepared the first transcript of this second version of the tale.

Ó hÍde demonstrates a very impressive handling of sources throughout, not only tracking down so much of Ó Dioráin's previously unpublished folklore at the NFC in the long chapter 8 but also in reconstructing in chapter 7 Oidhche Sheanchais's reception following its eventual release in cinemas in Ireland in March 1935. That opening had none of the ceremony of the premiere in May 1934 of Man of Aran, which was attended by significant members of the Irish government, along with Flaherty and his cast. While his image briefly flashed on the silver screens of Dublin and Cork, Seáinín Tom Ó Dioráin remained in Inishmore.

Denis Condon lectures on cinema at the Departments of English and Media Studies, Maynooth University, Ireland. His research focuses on early cinema, and his publications on this subject include the book Early Irish Cinema, 1895-1921 (2008), and articles in such journals as Early Popular Visual Culture, Screening the Past, Alphaville and Field Day Review. His co-edited collection Experiencing Music and Visual Cultures: Threshold, Intermediality and Synchresis has just been published by Routledge, and he is currently working on a monograph on Ireland's First Cinemas and a research blog at https://earlyirishcinema.com/.

denis.j.condon@mu.ie

Women in the Irish Film Industry: Stories and Storytellers

Edited by Susan Liddy

Cork: Cork University Press, 2020. 258 pp.

ISBN: 978-1-78205-373-6

Reviewer: Abigail Keating (University College Cork, Ireland)

As with any in-depth discussion of gender in contemporary cinema, the contexts that need to be set out at the beginning of a study on women in Irish film are manifold, stretched across society and culture, practice and representation, and questions of the prevailing inequalities within the industry in Ireland and beyond. Editor Susan Liddy establishes the historical 
circumstances and contemporary conditions from which her collection will unfold through a concise overview of a number of overlapping trends and topics: firstly, of gender parity under an international rubric and Irish cinema's likeness to other national film industries; of women's roles in society (and their status within the Irish Constitution); of the discursive significance of the Celtic Tiger period and its aftermath; of the Waking the Feminists movement from late 2015; of, what is often referred to as, the "fourth-wave" feminist context in which the latter played out via social media; and, finally, of the notable shift that has taken place since 2015 -evident through Screen Ireland's policy that aims to tackle gender disparity ("Six Point Plan on Gender Equality"), advocacy groups such as Women in Film and Television Ireland (WFT) working for gender equality within the Irish film industry, and the support of gender quotas by the Writers Guild and the Screen Directors Guild. Liddy weaves key points on the significance of the global backdrop with the nuances of an Irish milieu. The chapters that are to follow, as she describes, "identify and challenge the inequalities, and the disenfranchisement of women, in the Irish film industry, which replicate, in many ways, women's position in Irish society and culture [...] echo[ing] the ongoing, vigorous international debates" regarding women practitioners (11-2). The lens is wide here - a necessary approach with a collection that is so crucial and so long overdue.

The book is divided into four sections: the past is delved into further under the heading of "Revisiting the Past"; practitioners are given centre-stage in "Practitioners and Production Culture"; activism and education are explored in "Changing the Conversation"; while it is the topic of representation, in its broadest sense, that comprises "Text and Context", which focuses on fiction, documentary and animation.

Beginning the collection of essays, Díóg O'Connell's "biographical recovery" of Ellen O'Mara Sullivan (17) takes us on a fascinating journey of unearthing her role in the Film Company of Ireland in the late 1910s. Along with being an interesting historical portrait of a specific time in the subject's life, this essay "is about giving agency, voice and identity" to O'Mara Sullivan and underlines the challenges of excavating women's stories within and contribution to early film history.

Women's voices are amplified throughout Liddy's collection, balanced with historical, political and sociocultural contextualisation, along with analytical probing. This is tangible in Liddy's own essay contributions to the study, firstly, through a qualitative exploration of the underrepresentation of women in funding awards and funding applications, based on interviews with fifty-five women writers and writer/directors (53); and secondly, through her interview with award-winning director, Emer Reynolds (The Farthest, 2017) who, among other insightful points, draws comparison between the importance of visibility in the realm of women in film and women in science - "If you can see it, you can be it" (103).

Indeed, visibility is a notable thread across the collection, both in terms of shining a light on the multifaceted contributions of women to Irish film and film culture and on the mechanics and intricacies of the industry that impede women's progression within it. One such contribution is Laura Canning's detailing of the career of producer/ director/ editor/ curator, Nicky Gogan, a still-relatively under-the-radar filmmaker, as Canning describes (67), in an essay that aims to respond to the general lack of academic attention paid to film producers. This is a particularly significant quest when one is reminded that fifty-five per cent of completed projects in Ireland between 2010 and 2015 had a woman producer attached (67). Following on from this, Maeve Connolly's essay delves into another underexamined area of scholarship, the "visibility and invisibility" of the cinematographer (83). Initially noting the complexities of which in a tangible or authorial sense, Connolly explores the strategies that have been employed by women cinematographers to increase their respective and collective prominence within the industry, before presenting two important case studies in Suzie Lavelle (The Other Side of Sleep, 2011) and Kate McCullough (Snap, 2011). Exclusion and inclusion 
are core themes of Anne O'Brien's evidence-based study on documentary practice and women's labour. Semi-structured, anonymised interviews with twenty filmmakers reveal a "push and pull" relationship, as O'Brien calls it (120), between women and the non-fiction sector of contemporary Irish film: how women are seen as important assets in the production of documentaries through the emotional skills and sensitivity that they can bring to a project, yet how the challenges and biases that they face are often acutely gendered.

A focus on Irish film culture across topics of activism, education and collaboration comprises a thematically intersecting feature of this collection. Annie Doona's chapter on film education looks at the current higher-education framework (in terms of women's entry into the industry), drawing data from mostly Dublin-based institutions that offer analytical and/or practical courses on film, and at the policy context for film education in the Republic more broadly. Doona's own data was gathered through a questionnaire sent to policymakers in film and film education, wherein their views were sought on topics of education and gender equality; from which a number of concluding recommendations for a multi-agency approach are derived. Karla Healion, Aileen O'Driscoll, Jennifer O'Meara and Katie Stone examine the activism at the heart of the Dublin Feminist Film Festival, launched in 2014, in the festival's enduring commitment to showcasing and celebrating the work of women artists. While drawing on feminist ideas from the 1970s, along with the socio-historical nuances of female representation in Ireland, the authors also anchor the festival in fourth-wave feminist practices.

The making of Laura Aguiar's fascinating project We Were There (2014) is documented in her chapter on collaborative filmmaking in Northern Ireland. Produced in partnership with the Prisons Memory Archive, the film features ten interviews with female relatives of prisoners and staff of the Maze and Long Kesh Prison, along with female prison workers, in a bid to place women at the centre of the predominantly male-dominated narrative of The Troubles. This is a valuable contribution not only to discourses around gender and practice, but also to scholarly questions of the gendering of conflict, and more specifically to the gendering of conflict in an Irish realm. Complementary to this, representations of The Troubles are also the focus of Sarah Edge's chapter on Pat Murphy's feature film Maeve (1981) and Anne Crilly's television documentary Mother Ireland (1988), where Edge presents the texts as feminist interventions that challenged the relations between feminism and nationalism in the 1980 s.

Conflict is also a key theme of Eileen Culloty's essay on filmmaker, Dearbhla Glynn, as Culloty recounts Glynn's documentary work on the topics of women and violence in the Democratic Republic of Congo, specifically positioning Glynn as a humanitarian filmmaker. Interestingly, Glynn's experiences as a woman filmmaker are noted with regard to facilitating her with access to authorities (how it is often easier for the "non-threatening" woman) and, similar to what was documented earlier by Anne O'Brien, in relation to the emotional skills of the woman documentarian in the context of a project with an especially sensitive subject matter (187).

The transnational focus continues in Isabelle Le Corff's essay on the work of Irish writer and director, Juanita Wilson, wherein Wilson's cinematic interest in human mistreatment and survival (notably, in her 2010 adaptation of Croatian novelist Slavenka Drakulić's As If I Am Not There) is linked to the broader matter of the Irish postcolonial experience, "as though centuries of distress in Ireland still permeated her imagery" (223). Lance Pettitt's retrospective analysis of the work of pioneer, Pat Murphy, also draws attention to the simultaneity of the local and the global that exists within women's filmmaking. Murphy as feminist filmmaker is explored through a twenty-first-century lens in recounting her earlier films alongside her more recent international documentary Tana Bana (2015). Such an exploration of the thematic trajectory of Murphy's work and the sociopolitical and 
sociocultural links between her contributions serve to underline just how crucial Murphy's vision continues to be to Irish cinema and within its discourses.

The sociocultural positioning of women also forms the basis of Ruth Barton's essay on women, motherhood and domestic space. An analysis of the "male/paternal homeplace", through its absence and its unforgiving presence (238-239), provides an interesting comparative backdrop in fleshing out the gendering of space and domesticity across Irish cinema. Barton examines contemporary case studies, then, which have rejected old gendered tropes; here, however, the author laments that many of these instances remain on the periphery of Irish cinema, in a nod to an earlier introductory point that Irish cinema's mainstream continues to be male-dominated (233). Also focusing on relatively mainstream productions within Irish cinema, the final chapter features Ciara Barrett's analysis of gender equality within Irish animation, including qualitative information on a survey taken by seventy professionals within the industry, where on- and off-screen gender representation is explored. Barrett also turns her attention to a textual analysis of Nora Twomey and Tomm Moore's The Secret of Kells (2009), Moore's Song of the Sea (2014) and Twomey's The Breadwinner (2017), emphasising the effectiveness of the female authorial voice. Following this, Liddy's final remarks conclude the collection by offering the preceding pages as a foundation for future research, in the hope that this study is the beginning of something greater than the scope of the chapters presented -as Liddy herself highlights, "[f]uture research could include [...] intersectionality and broader issues of diversity and inclusion", among other urgent topics of significance (271).

One of Women in the Irish Film Industry's most notable strengths is the presence of a shared vision. Not to say that one can reduce the range of topics, methodologies and perspectives explored across the collection to a single vantage point; rather it reflects a coherency of passion - the work is offered with an ellipsis at the end, and each of the authors is committed to the cause of gender parity. To be in dialogue with one another, to share a goal, is a rare feature of an edited collection of this size. I commend Susan Liddy for achieving this, and for providing our discipline, in Ireland and beyond, with such an imperative resource.

\section{Works cited}

"Six Point Plan on Gender Equality". 30 September 2020. Screen Ireland. https://www.screenireland.ie/about/gender

Abigail Keating is Lecturer in Film and Screen Media at University College Cork. She is the author of the forthcoming book Women in Irish Film: Identity and Autonomy on the Contemporary Screen (Amsterdam University Press). Her previous work has appeared in such journals and anthologies as Studies in Documentary Film, New Cinemas: Journal of Contemporary Film, Film-Philosophy, Amateur Filmmaking: The Home Movie, the Archive, the Web, Routledge Encyclopedia of Citizen Media (forthcoming) and The Body Onscreen in the Digital Age: Essays on Voyeurism, Violence and Power (forthcoming). She is also a cofounding editor of Alphaville: Journal of Film and Screen Media.

abigail.keating@ucc.ie 
Resilient Reporting: Media Coverage of Irish Elections since 1969

Michael Breen, Michael Courtney, Iain McMenamin, Eoin O’Malley and Kevin Rafter

Manchester: Manchester University Press, 2019. iv + 176 pp.

ISBN: 9781526119988

Reviewer: Niamh Kirk (University College Dublin, Ireland)

Resilient Reporting is an examination of election news coverage in Ireland since the midtwentieth century, revealing a shift in the approach to electoral and political journalism. It inspects the character of election coverage across a number of key areas by establishing the evolution of the Irish media system, media responses to political developments, the role of the economy, gender biases, political party leaders and the personalisation of politics, commercialisation of election coverage, and finally, economic crisis coverage.

Three broad hypotheses are addressed throughout this book. Firstly, it questions the extent to which the norms of critical impartiality are sustained over time. Secondly, it examines the degree of shift towards hypercritical infotainment. And thirdly, it questions how exogenous factors have reshaped election reporting in Ireland. The title of the book is fitting given the core finding that in the evolution of Irish journalism, election coverage has largely remained resilient in a critical approach despite the changes in the wider system and potential for a shift towards "infotainment".

This book provides a comprehensive review of the coverage of Irish politics in the main Irish news sources over fifty years. The longitudinal approach provides a critical insight into political news reporting by charting transformative developments in Irish news media while identifying the retention of core journalistic values over a long period of time.

Taking a computational approach to the analysis of framing, tone and distribution of coverage across several key issues, it uses a substantial dataset consisting of some twenty-five million words derived from a large sample taken from across newspapers, radio and television. As well as comparing political coverage it also compares mediums, online to TV and radio, to establish if changes may be happening in one sector more so than another.

The underlying investigation throughout this book is the evolution of Irish political and electoral news coverage and asks whether critical impartiality is a norm or whether election journalism has succumbed to hypercritical infotainment as it has elsewhere. Furthermore, it examines the extent to which exogenous factors, such as changes in the media system, professional norms and technology, have reshaped election reporting in Ireland.

It argues that there was a reduction of partisanship coverage in Irish media since the 1960s which is shaped by wider changes in the social context and professional norms resulting in a shift towards what the authors describe as "critical impartiality". The core of the shift, they argue, is a move away from reverence reporting on political and religious authorities, to engaging in debates, nuanced coverage and accountability.

While arguing that election coverage in Ireland more recently has retained a critical and nuanced approach that values critical analysis reporting, it finds that there is overt negative coverage of Sinn Féin. In this instance it questions the legitimacy of such coverage and suggests that this is an area where Irish reporting, to some extent, fails to meet its own standards.

The team behind Resilient Reporting largely come from the Departments of Law and Government (Iain McMenamin, Eoin O'Malley and Michael Breen) and Communications (Kevin Rafter) at Dublin City University, Ireland, working with statistician Michael Courtney. The authors bring a wealth of experience to the topic and the collaborative, interdisciplinary approach renders a comprehensive and innovative review of the coverage of Irish politics. 
This book would be of benefit to scholars of political communication, Irish journalism, history of Irish media and more broadly anyone comparing media systems. Because the chapters are thematically grouped into the key factors that might shape election coverage, such as commercialisation and gender, this book would also be of benefit to scholars in economics and sociology.

The introductory chapter situates the broad theoretical approach to media systems, arguing that Hallin and Mancini's (2004) concept of media systems is a dynamic pathdependent approach whereby evolutions in any one of the three institutions that make up a media system can create a domino effect that changes the others. The core theoretical hypothesis of this book is outlined here. It asks if the evolution of Irish election coverage within the liberal media system over time resulted in a shift from critical impartiality to include hypercritical infotainment, with exogenous factors running in parallel shaping developments.

Chapter two offers an outline of the evolution of the political and media landscapes in Ireland over the past fifty years. It tracks i) developments in party politics, such as the emergence of a consensus system; ii) the emergence of new parties and their impact on the political ecosystem; iii) the recent economic context; and iv) social changes that anticipate an impact on media coverage, including lessened gender bias and less deference to former authorities such as the church. It describes some of the developments in the Irish media system, including the impact of advancements in communications technology and commercialisation.

Chapter three focuses on the media and political change, charting the framing, tone and distribution of election coverage over time. Here the authors describe the concepts of "hypercritical infotainment" and "critical impartiality". Hypercritical infotainment focuses on media as an agent of change and the imposition of media logic on politicians, while critical impartiality is considered a bulwark of stability. Here, little increase in characteristics of hypercritical infotainment is found, such as negative tone, and concludes that there has not been an overall shift towards hypercritical infotainment and argues that critical impartiality remains the norm.

Chapter four turns attention to the third of the book's core ideas, the exogenous factors shaping election coverage. This chapter addresses the influence of the economy on election coverage. Perhaps unsurprisingly it finds poor government performance in the economy results in more negative coverage in election news. However, somewhat surprisingly, positive government performance does not generate more positive coverage but rather has no effect.

Continuing the examination of exogenous factors, chapter five looks at gender in election coverage, noting that there is a gender bias in Irish politics with men "severely overrepresented in the executive and legislature" (76). It argues that previous election coverage of female candidates was less focused on the "political" although more positive in tone than today. Over time this tone shifted and by 2016 little difference in sentiment between the genders is found in election coverage. Although, it does stress that female candidates were under-reported on in comparison to their male counterparts in the 2016 General Election.

Chapter six focuses on leadership and personalisation in election coverage and considers whether Irish election coverage leans more towards discussions of policy, or if a game or horse race frame is more prevalent. Reiterating the role of critical impartiality as a norm, it finds little increase in the focus on leadership.

Chapter seven addresses the commercial interests of newstitles and election coverage. It questions whether the more vulnerable a newstitle is to commercial decline would induce more negativity in election coverage. It finds no association between the two nor any association between an increase in competition framing in relation to market vulnerability. 
Chapter eight looks to the issue of the economic and financial crises, focusing on the 2011 election. It asks, "When does poor economic performance become a crisis, and what are the implications of a crisis for media coverage?" (128) and shows that the economic crises at the time shaped changes in framing of the election over the course of the campaign, with the news media shifting focus to economic policy issues.

The final chapter concludes with the argument that there has been little shift in Irish coverage of elections towards a hypercritical infotainment style and has largely maintained a critical impartial approach despite evolution in the commercialisation of news media, and changes in the profession of journalism and public attitudes towards it. This underlines the theme carried in the title of the book, that Irish political election news is resilient to the potential detrimental effects of profound changes within and outside of the Irish media system.

Additionally, it includes comprehensive appendixes about Irish elections since 1969 and the data and methodology which are useful in themselves for understanding the context of Irish elections and election coverage as well as the innovative methodological approach that applies a series of computational methods to answer the main and operational research questions.

The authors provide clear descriptions of their computational methodological approaches noting some of the limitations. The sample from 1969-2016 is focused on two main news titles, the Irish Independent and the Irish Times in this regard, some of the analysis focuses on elite media. However, this is mitigated by the more comprehensive analysis of the more recent 2016 elections, which includes a wide range of traditional and new media. So, while offering insight into developments in elite legacy media historically, it provides a comprehensive depiction in the contemporary state of political coverage.

Resilient Reporting offers a welcome insight into the mediation of political and electoral developments in Ireland that also identifies what content was in circulation among the Irish electorate at various phases of evolution and how key internal and external factors influenced journalism. The longitudinal approach offers an important view of the evolution of election coverage including the representation of political parties, leaders and critical policy issues. Similarly, the comprehensive approach to the 2016 election provides an important analysis of the current nature of coverage and what shapes it.

This book underlines how guiding ethical and professional principles in Irish media have prevented the degradation of political journalism during elections. Despite all the internal and external factors that could have transformed or compromised the Irish political news system, it has largely retained its integrity. This is an important and substantial contribution to scholarship in Irish journalism studies and Irish political studies.

\section{Works cited}

Hallin, Daniel C., and Paolo Mancini. Comparing Media Systems: Three Models of Media and Politics. Cambridge: Cambridge University Press, 2004.

Niamh Kirk is the postdoctoral researcher at the School of Information and Communication Studies in University College Dublin on the Microsoft Newman Fellowship for Digital Policy, a digital methods educator at the School of Sociology, NUI Maynooth and a communications lecturer in the Department of Communications, Dublin City University. She has a $\mathrm{PhD}$ focused on transnational digital journalism and migration.

niamh.kirk@dcu.ie 
How Belfast Got the Blues: A Cultural History of Popular Music in the 1960s

Noel McLaughlin and Joanna Braniff

Bristol: Intellect, 2020. $\mathrm{x}+481 \mathrm{pp}$.

ISBN: 9781789382747

\section{Reviewer: Áine Mangaoang (University of Oslo, Norway)}

Over the past few decades, scholarship on music and place is well-established, from studies on music and national identity more broadly (Bohlman 2004; Radano 2003) to research on musical pathways within major cities as well as smaller towns (Finnegan 1989; Shank 2012). While publications on the music of Anglophone countries have received disproportionally high representation to date, recent years have witnessed a shift towards the peripheries in popular music studies. The result is more invigorating, illuminating subject matter, as well as innovative methodological and theoretical approaches, as scholars look towards the periphery in search for new insights, mindful and sensitive to spaces of difference (see, for e.g., Balance 2016; Hall et al 2019).

Uncovering the hidden histories of popular music in Northern Ireland's capital city forms the heart of Noel McLaughlin and Joanna Braniff's recent book How Belfast Got the Blues: A Cultural History of Popular Music in the 1960s. A book on this topic, taking into account Belfast's peripheral geographical location -in the far north of Ireland, physically separate from the UK, at the edge of Europe- and the politically complex statelet identity fraught with memory wars, seems to have awaited authors with the expertise that McLaughlin and Braniff possess. The co-authors McLaughlin (a popular music historian, well-known for his scholarship on Irish popular music) and Braniff (with background in Northern Irish politics and journalism) present a unified collaboration that provides a deep dive into Belfast's sociopolitical and cultural history. An important and much welcome book to the fields of Irish studies, popular music studies, and beyond, this substantial work explores the largely overlooked role of the city Belfast within local and global histories of popular music.

As a whole the book traces an arc across Belfast's popular music and politics of the long sixties, offering a direct challenge to the "assumption that the periphery has nothing to tell the centre" (15). The book's eight sizeable chapters plus an introduction focus on key events in the years 1964 -a pivotal year for popular music, both in Belfast and internationally (Chapter 1), 1966 -the summer of love that Northern Ireland's politics rejected (Chapter 7), and 1967-1968 -mapping the musical and political landscape at Ulster's crossroads (Chapter 8). Other chapters, that could likewise almost serve as standalone books in and of themselves, provide comprehensive accounts of significant artists from the region such as Them and Van Morrison (Chapter 4 and 5) and the Northern-Irish blues singer Ottilie Patterson (Chapter 6). While Chapter 4 opens boldly -and some may say erroneously- claiming that Van Morrison is "[Belfast and] Ireland's most revered and enduring popular music artist" (172), there is no denying Morrison has certainly been the subject of some detailed biographies (as well as countless news articles and high-profile court cases, more recently). The two chapters that follow explore the early days of the band Them, alongside a parallel narrative of Belfast's lively music scene with visits from touring acts like the Rolling Stones, and Them's play (or plagarisation) on the Beatles adverts for their 1964 residency at the Maritime Hotel. Recurring characters in this book include the Solomon family, especially Philip Solomon, the Belfast-born concert promoter, record producer and band manager who managed Them along with other Irish and Northern Irish artists including The Bachelors, Phil Coulter, and The Dubliners. The importance of individuals like Solomon in shaping (Northern) Ireland's music industry is interwoven across more than half of the book's eight chapters, as the authors vividly detail the vital role of music management in supporting music scenes, fashioning 
popular taste, and manufacturing musical stars.

Chapter 2 takes a different approach than the other chapters, connecting Belfast's peripheral status to popular music's centre by investigating the mysterious surroundings of The Rolling Stones' seldom seen film Charlie is My Darling (1966). Based on two days in the life of the Stones during their tour of Ireland in '65, this novel account reassesses the Stones' legacy and offers new insights into the band drawn from their debut film's near disappearance. In another approach again, Chapter 3 uses Belfast's legendary music venue of the Maritime Hotel -the so-called birthplace of rhythm 'n' blues in Belfast- as a starting point to delve into issues of how popular music histories are curated and gradually become formalized, and how, why and which heritage initiatives become state-sanctioned. In an era when music tourism has become a lucrative industry in many regions, cities are regularly competing with each other for access to economic regeneration funds, and the opportunity for commercially-driven music heritage initiatives have reached an all-time high, such discussions are indeed timely.

A recurring theme throughout the book is that of those absent from history may well be as significant as those present, as the authors point to many of the gaps in Irish popular music research and recognition to date. McLaughlin and Braniff are to be credited for foregrounding some of (Northern) Ireland's forgotten figures of popular music, in particular the representation of women. Ottilie Patterson is one such figure, who has gone down in history for her work with the Chris Barber Jazz Band and for performing with Sister Rosetta Tharpe and Muddy Waters, among others; yet her work has rarely received critical attention in its own right. Chapter 6, "Irish Lady Sings the Blues", attempts to right this wrong, where McLaughlin and Braniff deliver a fresh narrative of Patterson's career. They document an earlier, vibrant blues scene in Northern Ireland stemming from the 1950s, and in doing so, challenge prevailing historiographies that consider British blues to have developed from a youth- and male-dominated R'n'B subculture in the early 1960s. The authors discuss many of Patterson's performances and recordings on both sides of the Atlantic, along with her composition and songwriting-style, and her unique musicality that blends her interpretation of the blues with an ostensibly Irish "yarragh" -that non-lexical intensity of feeling that is so often heard in Irish traditional song. Remarkably, the authors never deflect from the knotty issues of Patterson's identity as a white woman inhabiting a musical form that stemmed from African American suffering. Instead, extensive nuance and consideration is given to Patterson's oeuvre as it intersects with ideas of race, whiteness and the blues. McLaughlin and Braniff go on to reveal how Patterson's career of singing the blues led to her actively working on anti-racist initiatives, including her foundational role in establishing the Stars Campaign for Interracial Friendship (SCIF) organisation, one of the precursors to the Rock Against Racism (RAR) movement. Suffice to say that the authors could easily have devoted the entire book to the immensely overlooked figure of Patterson alone; one can hope that after reading this chapter a future scholar may be inspired to take on the mantle.

The book's final chapter, while it covers the initial release of Van Morrison's now cult classic Astral Weeks in late 1968, it takes another more interesting look at a conspicuous absence from the popular music history books in the form of the utopian 'Pop for Peace' concert. This music gathering took place on the south of Belfast in August 1968 was the first outdoor peace concert held in Northern Ireland, included messages of support from John Lennon and Yoko Ono, attracted 10,000 people and preceded Woodstock -the most mythologized music festival of the decade- by two weeks, yet it is virtually non-existent in accounts of Northern Ireland in the 1960s. Again the discussion of memory wars and the question of "whose 1960s, whose NI and ultimately whose agenda" (433) is being advanced in Northern Ireland's cultural memory is brought to the surface.

How Belfast Got the Blues provides a meticulous account of Belfast's popular music 
culture and politics of the 1960s, going beyond the big names and greatest hits of the decade and, crucially, includes some of those disregarded in previous historical accounts. Released in what can be considered a bumper year for (Northern) Irish popular music scholarship with Stephen Millar's Sounding Dissent: Rebel Songs, Resistance, and Irish Republicanism (University of Michigan Press) and Áine Mangaoang, John O'Flynn and Lonán Ó Briain's Made in Ireland: Studies in Popular Music (Routledge), How Belfast Got the Blues marks an incredibly valuable contributions to both Irish studies and popular music studies that both celebrates and critiques the multifaceted role of Belfast's music scenes and its international impact. At nearly 500 pages of sophisticated analysis, the book is reasonably priced in paperbook and e-book formats, offering historical nuggets and exceptional value per page.

At the very heart of the book lies the belief that popular music is put to the service of representation of Northern Ireland's ambitions as well as revealing the statelet's veiled repressions through lucid and illuminating evidence of the critical role popular music played in shaping Northern Irish identity. Far from Belfast being just a "troubled city" or an "obscure periphery", by the book's end the reader is left in full agreement with McLaughlin and Braniff's convincing analysis that Belfast had the capacity to be "ahead of the curve" (446) not only in relation to pop music but also in progressive political thinking, such as the compelling discussion of politician-activist Bernadette Devlin-McAliskey.

By tuning into the various voices from the periphery, How Belfast Got the Blues showcases how pop groups, overlooked artists and little-known entertainers had a profound effect on official political culture not only in Northern Ireland and the Republic of Ireland but in Britain and the US too. McLaughlin and Braniff's book offers a simple yet nonetheless significant message for the future of Irish (popular music) studies: that as scholars, educators and activists, we have a responsibility to shine a light on the musicians and actors who played an essential part in shaping our local music scenes in order to reveal what is remembered and what is excluded, as absences may be even more critically significant than presences.

\section{Works cited}

Balance, Christine Bacareza. Tropical Renditions: Making Musical Scenes in Filipino America. Durham, N.C.: Duke University Press, 2016.

Bohlman, Philip V. The Music of European Nationalism: Cultural Identity and Modern History. Santa Barbara, California: ABC-CLIO, 2004.

Finnegan, Ruth. The Hidden Musicians: Music-Making in an English Town. Cambridge: Cambridge University Press, 1989.

Hall, Porbjörg Daphne, Nicola Dibben, Árni Ingólfsson and Tony Mitchell, (eds.) Sounds Icelandic: Essays on Icelandic Music in the 20th and 21st Centuries. London: Equinox, 2019.

Mangaoang, Áine, O’Flynn, John and Lonán Ó Briain, (eds.) Made in Ireland: Studies in Popular Music. London: Routledge, 2020.

Millar, Stephen R. Sounding Dissent: Rebel Songs, Resistance, and Irish Republicanism. Ann Arbor: University of Michigan Press, 2020.

Radano, Ronald M. Lying up a Nation: Race and Black Music. Chicago: University of Chicago Press, 2003.

Shank, Barry. Dissonant Identities: The Rock'n'Roll Scene in Austin, Texas. Middletown, CT: Wesleyan University Press, 1994.

Áine Mangaoang is a musicologist at the University of Oslo, Norway. Her recent books include the co-edited volume Made in Ireland: Studies in Popular Music (Routledge, 2020) and the monograph Dangerous Mediations: Pop Music in a Philippine Prison (Bloomsbury, 
2019). Her research on popular music, (dis)ability, place and politics is published in the edited volumes Beyoncé (University of Indiana Press, 2020), The Routledge Companion to Popular Music Analysis (2018), and in the Journal of World Popular Music (2019).

ainem@imv.uio.no 